\title{
The Role of Complement in Age-Related Macular Degeneration: Heparan Sulphate, a ZIP Code for Complement Factor H?
}

\author{
Alex Langford-Smith ${ }^{a}$ Tiarnan D.L. Keenan ${ }^{a-c}$ Simon J. Clark ${ }^{b, c}$ Paul N. Bishop ${ }^{\text {b, c }}$ \\ Anthony J. Day ${ }^{a}$ \\ aWellcome Trust Centre for Cell-Matrix Research, Faculty of Life Sciences, and ${ }^{b}$ Centre for Hearing and Vision Research, \\ Institute of Human Development, University of Manchester, and ${ }^{\mathrm{C} C e n t r e ~ f o r ~ A d v a n c e d ~ D i s c o v e r y ~ a n d ~ E x p e r i m e n t a l ~}$ \\ Therapeutics and Manchester Royal Eye Hospital, Central Manchester University Hospitals NHS Foundation Trust, \\ Manchester Academic Health Science Centre, Manchester, UK
}

\section{Key Words}

Complement factor $\mathrm{H} \cdot$ Age-related macular degeneration . Heparan sulphate $\cdot$ Tissue-specific immune recognition

\begin{abstract}
Age-related macular degeneration (AMD) is the leading cause of blindness in developed nations and has been associated with complement dysregulation in the central retina. The $\mathrm{Y} 402 \mathrm{H}$ polymorphism in the complement regulatory protein factor $\mathrm{H}(\mathrm{CFH})$ can confer a $>5$-fold increased risk of developing AMD and is present in approximately $30 \%$ of people of European descent. CFH, in conjunction with other factors, regulates complement activation in host tissues, and the $\mathrm{Y} 402 \mathrm{H}$ polymorphism has been found to alter the protein's specificity for heparan sulphate (HS) - a complex polysaccharide found ubiquitously in mammals. HS, which is present on the cell surface and also in the extracellular matrix, exhibits huge structural diversity due to variations in the level/pattern of sulphation, where particular structures may act as 'ZIP codes' for different tissue/cellular locations. Recent work has demonstrated that CFH contains two HS-binding domains that each recognize specific HS ZIP codes, allowing differential recognition of Bruch's membrane (in the eye) or the glomerular basement membrane (in the kidney).
\end{abstract}

Importantly, the $\mathrm{Y} 402 \mathrm{H}$ polymorphism impairs the binding of CFH to the HS in Bruch's membrane, which could result in increased complement activation and chronic local inflammation (in $402 \mathrm{H}$ individuals) and thereby contribute to AMD pathology.

(c) 2013 S. Karger AG, Basel

\section{Introduction}

Age-related macular degeneration (AMD) is the leading cause of blindness and visual impairment in developed countries and its prevalence is likely to increase over time, given the ageing population [1]. There is an increasing body of genetic [2-6] and biochemical [7] evidence that AMD is a disease of complement dysregulation, and therefore, that the innate immune system has a key role in the pathogenesis of the disease.

$\mathrm{AMD}$ is a slow, progressive, degenerative disease strongly associated with ageing that usually occurs after the age of 50 years. In populations of European ancestry, the prevalence of advanced AMD is $1.4 \%$ at 70 years of age,

\section{A.L.-S. and T.D.L.K. contributed equally to this work.}

\begin{tabular}{ll}
\hline KARGER & $\begin{array}{l}\text { (c) 2013 S. Karger AG, Basel } \\
1662-811 X / 13 / 0064-0407 \$ 0.00 / 0\end{array}$ \\
E-Mail karger@karger.com & $\begin{array}{l}\text { This is an Open Access article licensed under the terms of } \\
\text { the Creative Commons Attribution 3.0 Unported license } \\
\text { www.karger.com/jin }\end{array}$ \\
& $\begin{array}{l}\text { (CC BY 3.0) (www.karger.com/OA-license-WT), appli- } \\
\text { cable to the online version of the article only. }\end{array}$
\end{tabular}

Prof. Anthony J. Day

Wellcome Trust Centre for Cell-Matrix Research

Faculty of Life Sciences, University of Manchester

Michael Smith Building, Oxford Road, Manchester, M13 9PT (UK)

E-Mail anthony.day@manchester.ac.uk 
rising to $5.6 \%$ at 80 and $20 \%$ at 90 years of age [8]. In the early stages of the disease, visual symptoms may be absent or minimal. However, in advanced cases, AMD leads to severely reduced central vision and loss of visual acuity. Clinically, AMD is subclassified into early, intermediate and late forms [9]. Early and intermediate forms are characterized by the presence of drusen, which are extracellular deposits containing proteins (including complement components) $[7,10]$ and lipids that accumulate between the retinal pigment epithelium (RPE) and Bruch's membrane (fig. 1a) $[9,11]$. The late form is subdivided into either atrophic ('dry') or neovascular ('wet') (fig. 2). Atrophic AMD is characterized by cell death in the retina and choroid in areas where significant levels of drusen have accumulated, whereas neovascular AMD is caused by new blood vessels growing from the choroid into the retina.

\section{The Role of Complement in AMD: Genetics}

Complement was first postulated to be involved in the pathogenesis of AMD following the discovery of complement activation products in drusen [10]. This suggestion has been strongly supported by genetic evidence, including the association of the $\mathrm{Y} 402 \mathrm{H}$ polymorphism in complement factor $\mathrm{H}(\mathrm{CFH})$ with an increased risk of AMD [see ref. 2-4, 6, and references within]. The $\mathrm{Y} 402 \mathrm{H}$ polymorphism, which results in a coding change of tyrosine to histidine at position 402 (position number 384 in the mature protein) $[12,13]$, is common in European-descended populations, with a recent meta-analysis of 26 studies estimating the prevalence of the $402 \mathrm{H}$ allele at $30 \%$ [4]. This meta-analysis also showed that $402 \mathrm{H}$ heterozygotes have a 2.3-fold and $402 \mathrm{H}$ homozygotes a 5.2 -fold increased risk of advanced AMD [4]. Interestingly, the high prevalence of the $\mathrm{Y} 402 \mathrm{H}$ polymorphism in people of European ances-

Fig. 1. Structures of the eye, CFH and HS; effect of CFH Y402H polymorphism on HS ZIP code recognition and complement regulation in Bruch's membrane. a Cross-sections of the eye (left) and the bottom half of the macula (right). IPM = Interphotoreceptor matrix. b Modular organization of CFH showing 20 CCP domains, the position of the $\mathrm{Y} 402 \mathrm{H}$ polymorphism and regions involved in ligand binding. c Domain structure of HS, containing NA, NA/NS and NS domains. Representative structures are shown for the highly sulphated NS domains [i.e. comprising the $\operatorname{IdoA}(2 \mathrm{~S})-\alpha 1-4-$ GlcNS $(3,6 \mathrm{~S})$ disaccharide], the NA regions (comprising GlcA- $\beta 1$ 4-GlcNAc) and a possible HS tetrasaccharide from the NA/NS region (comprising GlcA- $\beta 1-4-G l c N S-\alpha 1-4-I d o A-\alpha 1-4-G l c N A c)$. R represents variable sites of sulphation, contributing to the huge diversity in HS structure. $\mathbf{d}$ Model showing possible functional dif- try fits with the hypothesis that the $\mathrm{Y} 402 \mathrm{H}$ polymorphism acted as a survival factor by having lower binding affinity for the bubonic plague bacteria Yersinia pestis [14].

Other genetic variations around the $\mathrm{CFH} / \mathrm{CFH}$-related protein (CFHR) gene cluster also modify the AMD risk including a relatively common deletion of CFHR1 and CFHR3, which is protective against AMD [5]. As shown in table 1 , several other genes in the complement pathway are also associated with AMD (but more weakly), including variants involving complement component 2 (C2), complement factor B (CFB), C3, C9 and complement factor I (CFI) $[2,15]$.

Alongside the CFH/CFHR locus on chromosome 1, there is also a strong association with a locus at $10 \mathrm{q} 31$, close to the ARMS2 and HTRA1 genes [2]. However, it is not clear which of these genes is affected, and additional work is needed to determine the nature of their involvement in AMD pathogenesis [2]. Other weak genetic associations have been made recently based on genomewide association studies, implicating angiogenesis, extracellular matrix and lipid metabolism in the pathology of AMD (table 1) [2, 3].

\section{The Role of CFH in AMD}

$\mathrm{CFH}$ has a key role in regulating the alternative pathway of complement; this $155-\mathrm{kDa}$ serum glycoprotein is composed of 20 complement control protein (CCP) domains, such that different regions of $\mathrm{CFH}$ recognize different ligands (fig. 1b). For example, $\mathrm{CFH}$ inhibits the formation of the alternative pathway $\mathrm{C} 3$ convertase by competing with factor $\mathrm{B}$ binding to $\mathrm{C} 3 \mathrm{~b}$ [or $\mathrm{C} 3\left(\mathrm{H}_{2} \mathrm{O}\right)$ ] via its $\mathrm{CCP} 1-4$ region; $\mathrm{CFH}$ also promotes the decay of existing $\mathrm{C} 3$ convertase by displacing factor $\mathrm{Bb}$. $\mathrm{CFH}$ acts as a cofactor for factor I in the inactivation of $\mathrm{C} 3 \mathrm{~b}$ to $\mathrm{iC} 3 \mathrm{~b}$ so that

ference between the $402 \mathrm{H}$ (AMD-associated) and 402Y forms of $\mathrm{CFH}$ in Bruch's membrane. The 402Y form of $\mathrm{CFH}$ (green) can bind to multiple sites on HS chains in Bruch's membrane due to its wide specificity for HS ZIP codes; the $402 \mathrm{H}$ variant (red) only binds to highly sulphated motifs within HS, meaning that fewer molecules of this CFH allotype localize to this extracellular matrix. $\mathrm{CFH}$ inhibits complement activation by acting as a co-factor for the factor-I-mediated inactivation of $\mathrm{C} 3 \mathrm{~b}$ to $\mathrm{iC} 3 \mathrm{~b}$; it also prevents the formation and accelerates the decay of the C3 convertase $\mathrm{C} 3 \mathrm{bBb}$. Thus, if insufficient CFH is present in Bruch's membrane, as is the case for the $402 \mathrm{H}$ variant, there will be increased activation of the complement cascade and the release of pro-inflammatory mediators, such as C3a.

(For figure see next page.) 
a
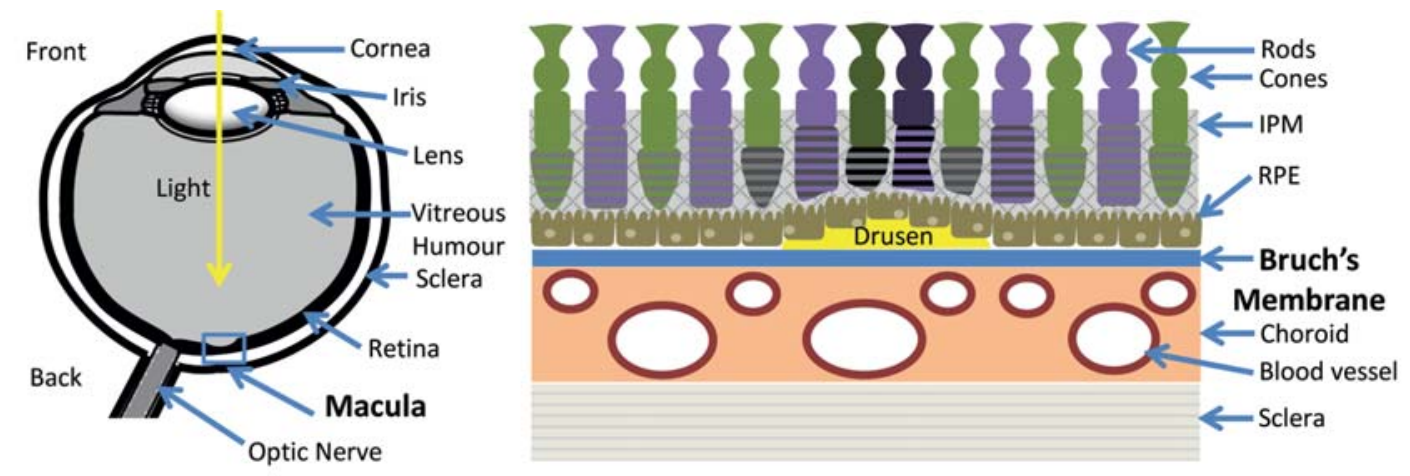

Bruch's membrane HS

Glomerular basement membrane HS

b

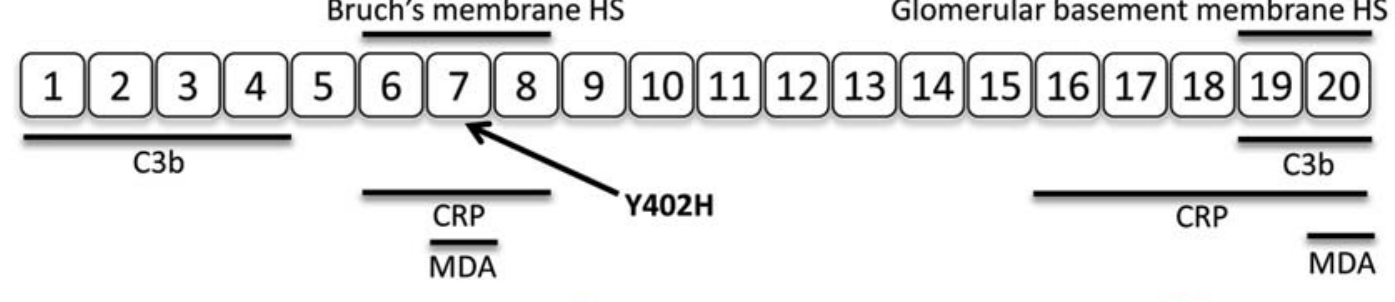

c

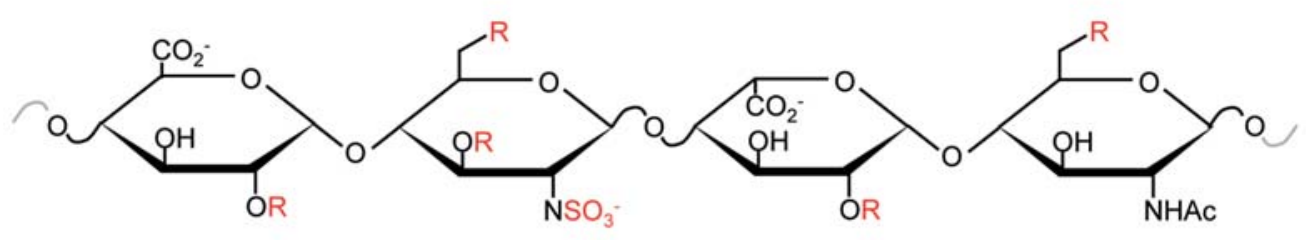

Heparan Sulphate

GlcA-GIcNS - IdoA-GIcNAc

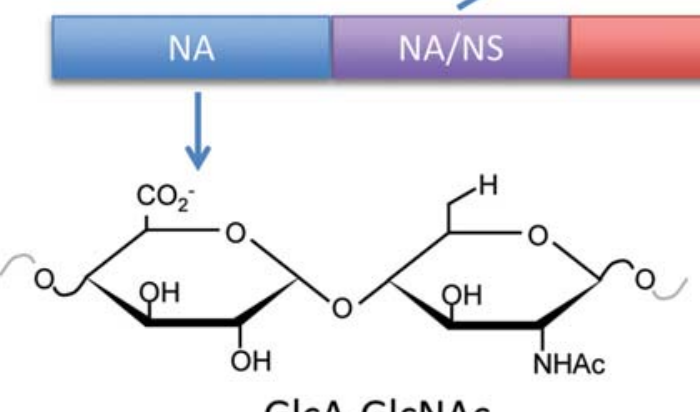

GIcA-GIcNAc

d

CFH $402 Y$

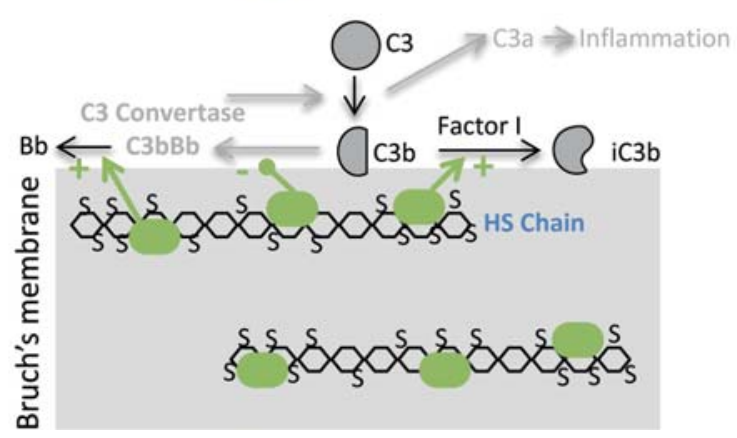

$$
\begin{array}{l|l|l}
\text { NS } & \text { NA/NS } & \text { NA }
\end{array}
$$

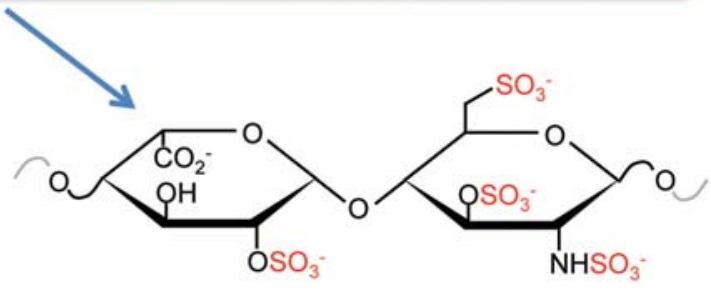

$\operatorname{IdoA}(2 S)-\mathrm{GlcNS}(3,6 \mathrm{~S})$

$\mathrm{CFH} 402 \mathrm{H}$

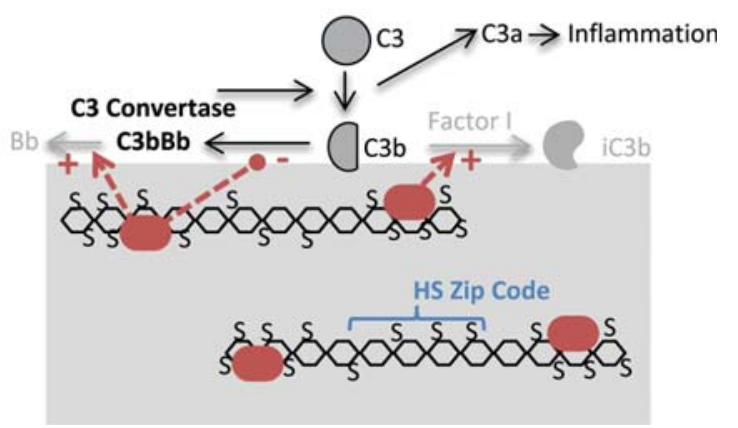


Fig. 2. Overview of the pathogenesis of AMD. Complement dysregulation [7, 10, 37] and oxidative stress [21, 44] have been implicated in causing/amplifying the inflammation central to AMD pathology. These processes are influenced by genetic effects [2-6, 51, 52] (table 1), denoted by grey arrows, and also environmental factors, highlighted with dashed arrows, including smoking [53] and the effect of a high fat diet [54].

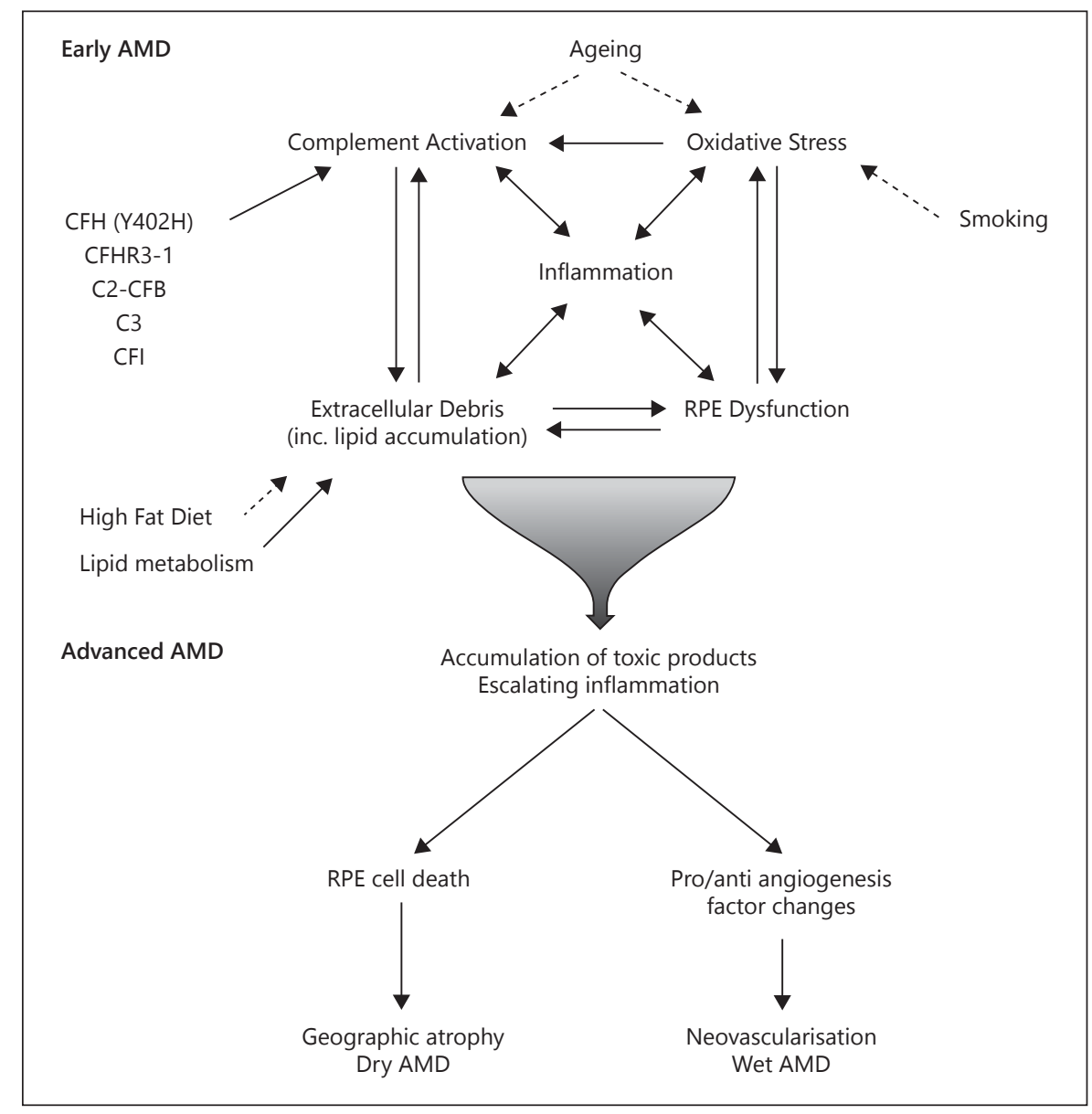

there is less available $\mathrm{C} 3 \mathrm{~b}$ for the formation of the $\mathrm{C} 3 \mathrm{con}$ vertase, $\mathrm{C} 3 \mathrm{bBb}$, or the $\mathrm{C} 5$ convertases, $\mathrm{C} 3 \mathrm{bBb} 3 \mathrm{~b}$ and C4b2a3b [13]. The CCP6-8 and CCP19-20 regions are important for binding to, amongst other things, heparan sulphate (HS), malondialdehyde (MDA) and C-reactive protein (CRP) [16].

Given the severity of the risk and the prevalence of the $\mathrm{Y} 402 \mathrm{H}$ polymorphism, there have been a number of studies that have investigated the functional effect on the ligand-binding properties of $\mathrm{CFH}$ : a coding change occurs in CCP7 (fig. 1b), and many studies have utilized a recombinant protein comprising CCP6-8 with either a histidine or a tyrosine at position 402 [17]. For example, differential binding of the $402 \mathrm{H}$ and $402 \mathrm{Y}$ allotypes has been observed to CRP, chondroadherin, DNA, fibromodulin, heparin/ HS, MDA, necrotic cells, Shiga toxin and Streptococcus M protein [18-22]. As described below, the dramatic effect of $\mathrm{Y} 402 \mathrm{H}$ on the interaction with the glycosaminoglycan (GAG) HS could provide a biochemical explanation for the role of this polymorphism in AMD [17, 23, 24]; how- ever, this does not exclude the possibility that its effect on other ligand-binding activities may also play some part.

Our previous work demonstrated that the $\mathrm{Y} 402 \mathrm{H}$ coding change alters the specificity for heparin/HS of $\mathrm{CFH}$ $[17,23]$. By selectively de-sulphating heparin, as a model of HS, it was shown that the CFH $402 \mathrm{H}$ (AMD-associated) variant requires a high degree of sulphation for high affinity binding [17]; however, the 402Y allotype has a much broader specificity for HS, meaning that it can interact with a wider range of HS structures in tissues (see below). Consistent with this, high-resolution structural analyses indicated that the residue at position 402 is directly involved in binding to heparin/HS and that the change from a histidine to tyrosine will likely affect the sulphation pattern that can be recognized [23]. In this regard, we found that, while the two CFH variants can bind similarly to the RPE cell layer in human macular tissue sections, the $402 \mathrm{H}$ form binds poorly (approximately 2 -fold less than $402 \mathrm{Y}$ ) to Bruch's membrane, where HS plays a major role in mediating these differential interactions [24]. 
Table 1. Summary of pathways and genes associated with AMD

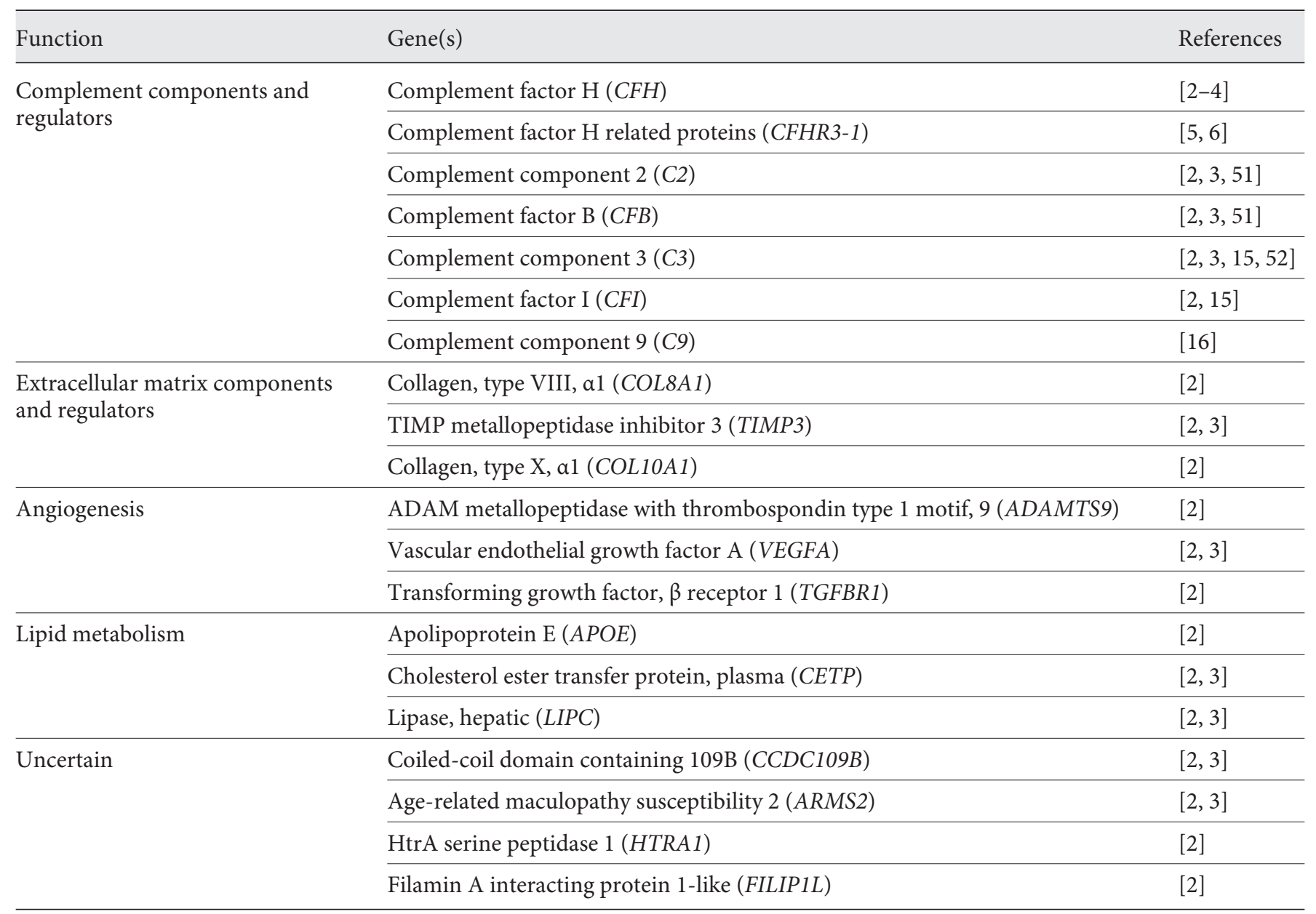

\section{HS: a ZIP Code for CFH}

HS is a GAG that is present on the surface of all cells and in the extracellular matrix; this polysaccharide is attached to particular core proteins to form HS proteoglycans, which have important roles in development, cell differentiation, signalling, tissue homeostasis and disease $[18,25-28]$. HS is formed of repeating disaccharides comprising a glucuronic acid (GlcA) or iduronic acid (IdoA) linked to $\mathrm{N}$-acetylglucosamine (GlcNAc) and is typically 50-200 disaccharides in length. The basic repeating disaccharide can be modified by sulphation at various positions to produce a large number of sequence permutations, giving rise to immense structural diversity (as is illustrated in fig. 1c). Additional complexity occurs through the formation of domain structures, with highly sulphated $\mathrm{N}$-sulphated (NS) regions interspersed within $\mathrm{N}$-acetylated (NA) regions that have undergone limited modifi- cation and consist mainly of GlcA-GlcNAc repeats. The NS domains are typically 3-8 disaccharides long and are modified by $\mathrm{N}$ - and $\mathrm{O}$-sulphation, with epimerization of most GlcA to IdoA; NA/NS domains flank the NS domains and comprise alternating $\mathrm{N}$-acetylation and $\mathrm{N}$-sulphation with a mixture of GlcA and IdoA and some variable O-sulphation. The number/organization of these different domains and the variability in the length of the HS chain further add to the complexity of HS.

Overall, the large degree of structural diversity in HS and its ubiquity in tissues allows it to play a major role in the regulation of physiological processes [25-28], i.e. via its interaction with many proteins and through the modulation of their functions. Given that the composition/ sequence of HS likely differs from one particular tissue microenvironment to another, this gives HS the potential to act as a ZIP code for a particular cellular/tissue location. In this regard, we have recently mapped the location 
of HS and its core proteins within the human eye $[29,30]$, showing that there is a distinct pattern of HS/HS proteoglycan structures within the different layers of the retina, choroid and sclera; this was performed using antibodies that recognize particular HS epitopes. For example, around the blood vessels of the inner retina (not shown in fig. 1a), there is HS with a high level of 6-O-sulphation, while in the inner limiting membrane, there are HS species with both high and low 6-O-sulphation; given that the binding and regulation of angiogenic growth factors (e.g. fibroblast growth factor 2 and vascular endothelial growth factor) requires 6-O-sulphation, local differences in HS structure may play a role in modulating the formation of blood vessels, e.g. preventing outgrowth into the vitreous from the neurosensory retina [29].

This analysis also showed that there is a diverse range of HS structures within Bruch's membrane, including $\mathrm{N}$-, 6-O- and 2-O-sulphated structures, 3-O-sulphated HS chains as well as structures with a low level of 2-O-sulphation [19]. In this regard, we have previously found that the $402 \mathrm{H}$ (AMD-associated) variant of $\mathrm{CFH}$ requires the presence of HS with 2-O- and/or 6-O-sulphation to support its binding to human Bruch's membrane, whereas $402 \mathrm{Y}$ can interact with HS lacking such sulphation [18, 24]. Thus, given the more restricted specificity of the $402 \mathrm{H}$, which requires highly sulphated structures for binding $[17,23]$, it seems likely that there may be relatively fewer HS sequences that can be recognized by $402 \mathrm{H}$ (compared to 402Y) in human Bruch's membrane, at least in the old donor tissues used in these studies [24,29]. Interestingly, $\mathrm{CFH}$ binding sites were only abundant within the RPE, Bruch's membrane and the choroid (e.g. around blood vessels), with low levels throughout the neurosensory retina (e.g. in the interphotoreceptor matrix) [24]. This indicates that the HS ZIP codes used by $\mathrm{CFH}$ are restricted to particular regions, despite HS being present throughout the eye.

Interestingly, the RPE, Bruch's membrane and choroid are sites that come into contact with complement components (e.g. from blood) and therefore require tight regulation to prevent unwanted complement activation; i.e. because of the continuous slow tickover of the alternative pathway that left unchecked would lead to the deposition of $\mathrm{C} 3 \mathrm{~b}$ and the amplification of complement, resulting in inflammation and tissue damage. While cell surfaces can be protected from complement by a number of endogenous cell-bound regulatory factors such as CD35, CD46, CD55 and CD59 [31], extracellular matrices, such as basement membranes (e.g. in kidney glomeruli and Bruch's membrane in the eye), do not possess these regulators and need to recruit $\mathrm{CFH}$ to protect themselves from aberrant complement activation $[18,20]$. $\mathrm{CFH}$ also plays an important role in self versus non-self recognition by being recruited to sites on host cell surfaces that contain a suitable localization signal, e.g. including HS ZIP codes [24].

\section{Tissue-Specific Host Recognition by CFH via HS ZIP Codes}

$\mathrm{CFH}$ contains two HS recognition domains, comprising CCP6-8 and CCP19-20 (fig. 1b), with mutations and polymorphisms in these regions being associated with AMD or the kidney disease atypical haemolytic uremic syndrome (aHUS), respectively, but not with both diseases [see ref. 32, and references therein]. Recently, we have investigated the GAG-binding properties of the CCP6-8 and CCP19-20 regions and have found that the former has a higher apparent affinity for heparin [32]. In terms of sulphate specificity, the CCP19-20 region is much more similar to the $402 \mathrm{H}$ variant of CCP6-8 (than $402 \mathrm{Y}$ ), being highly sensitive to the removal of sulphate groups. However, their specificities are different since the removal of 6-O-sulphates, for example, has a larger effect on the binding of CCP19-20 compared to CCP6-8 402H. Thus, the CCP6-8 and CCP19-20 regions might be expected to recognize different HS structures in human tissues. Consistent with this, we have found that it is the CCP6-8 region that makes the major contribution to the binding of CFH to Bruch's membrane, with CCP19-20 playing only a minor role [32]; previously, we have shown that about $70 \%$ of the binding sites for CCP6-8 in Bruch's membrane are composed of HS [24]. Conversely, the CCP19-20 region plays the dominant role in the recognition of kidney glomerular basement membrane by $\mathrm{CFH}$, which again is predominantly mediated by HS [32]. Interestingly, in a recent study, the HS ZIP code recognized by $\mathrm{CFH}$ in another region of the kidney (renal tubular epithelial cells) was found to be distinct to that of properdin, a positive regulator of the complement system [33]. This illustrates that different HS ZIP codes within the same tissue can play a role in the differential control of the binding of complement regulatory proteins.

As noted above, the two HS-binding domains of $\mathrm{CFH}$ have different specificities allowing the recognition of distinct HS ZIP codes and the tissue-specific localization of CFH [32]. Thus, our studies have provided a biochemical explanation for the organ-specific effects of mutations/polymorphisms in the $\mathrm{CFH}$ gene, where $\mathrm{Y} 402 \mathrm{H}$ (in 
CCP7) is associated with AMD, whereas those in CCP1920 are all associated with aHUS. One exception is the rare penetrant R1210C mutation in CCP20 that confers a high risk of developing AMD [34]. While the mutation is thought to reduce heparin binding [35], more importantly, it also results in CFH, forming a covalent complex with serum albumin [36] that would likely have a dramatic effect on the transport of this complement regulator through Bruch's membrane [32].

\section{The Role of CFH in AMD Pathogenesis}

As noted above, we have found that the AMD-associated $402 \mathrm{H}$ form of $\mathrm{CFH}$ binds relatively poorly to $\mathrm{HS}$ in Bruch's membrane compared to $402 \mathrm{Y}$ [24]. In vivo, this could lead to a decreased ability of the $402 \mathrm{H}$ variant of $\mathrm{CFH}$ to localize to Bruch's membrane, resulting in impaired regulation of the alternative pathway of complement and the production of pro-inflammatory mediators (fig. 1d) $[18,20,24]$. This would be expected to result in chronic local inflammation, which is thought to be a key pathogenic feature in AMD (fig. 2) [7, 10, 37]. It has been shown that the CFH Y402H polymorphism is not associated with significantly increased systemic complement activation $[38,39]$ adding weight to its function being locally mediated. Consistent with this, individuals who are homozygous for $\mathrm{CFH} 402 \mathrm{H}$ have been found to have significantly higher levels of complement activation (e.g. membrane attack complex) and elevated markers of inflammation in Bruch's membrane and/or choroid [40, 41]. However, in addition to the effect of $\mathrm{Y} 402 \mathrm{H}$ on HS binding, this polymorphism in $\mathrm{CFH}$ has also been clearly implicated in other processes that could contribute to inflammation and AMD pathology.

In this regard, oxidative stress results in RPE damage/ dysfunction and the generation of the pro-inflammatory MDA by lipid peroxidation of membrane phospholipids $[21,42]$. The presence of MDA on the surface of RPE cells acts as a binding site for $\mathrm{CFH}$ via CCP7 or CCP20 (fig. 1b), inhibiting complement activation and also the MDA-induced expression of IL- 8 by monocytes and macrophages [21]. Given that the $402 \mathrm{H}$ variant of $\mathrm{CFH}$ has reduced the binding affinity for MDA (compared to 402Y), less CFH will be recruited to the 'oxidized' cell, meaning that complement activation and chronic inflammation may occur. Similarly, pentameric CRP binds to damaged/necrotic cells and undergoes conformational changes to monomeric CRP [43], which then acts as a binding site for $\mathrm{CFH}$. The CFH-CRP interaction is also impaired by the $\mathrm{Y} 402 \mathrm{H}$ mutation, which may lead to increased complement activation and inflammation in the macula of individuals carrying the $402 \mathrm{H}$ allele $[22,44]$.

There are currently many unanswered questions regarding the pathogenesis of AMD. In particular, it is far from clear what initiates the disease process or, indeed, the relative importance/timing of the various mechanisms implicated above; however, as noted before, complement dysregulation and inflammation have been identified as having a central role (fig. 2). One important question is why AMD symptoms only manifest over the age of 50 years (even in individuals with a strong genetic predisposition). Our studies have found that the $402 \mathrm{Y}$ and $402 \mathrm{H}$ variants of CFH have an inherent difference in their ability to bind HS in Bruch's membrane [24]. Here we used old, but non-AMD, donor tissue, raising the possibility that age-related changes in HS ZIP codes, if they occur in the eye as they have been shown to in the aorta [45], could contribute to the disease mechanism [20]. Further work is needed to determine whether AMD pathology results from normal changes in tissue structure with age in combination with genetic and environmental risk factors.

\section{Animal Models of AMD - A Different Zip Code?}

Animal models have great utility in understanding disease pathogenesis and in testing novel therapeutics. In AMD, a large number of rodent models have been developed [for a review, see ref. 46]; however, none of these models recapitulate all aspects of the human disease. Despite structural similarities between murine and human eyes, mice do not have a macula (i.e. a region of the retina with a higher proportion of cones) and do not suffer from AMD.

Mice lacking CFH have been created and, at 2 years of age, these mice demonstrated some loss of photoreceptors and deposition of complement in the retina [47]; however, a thinning of Bruch's membrane was observed rather than a thickening, as is observed in man [11]. This mouse model indicates that the absence of CFH (with no other initiating factor) leads to dysregulation of the innate immune system causing pathology in the retina. To elucidate the role of the $402 \mathrm{Y} / \mathrm{H}$ variants, this $\mathrm{CFH}$ null mouse was modified to express a humanized form of $\mathrm{CFH}$ containing the mouse CCP1-5 and CCP9-20 and the human CCP6-8 containing either the $402 \mathrm{H}$ or $402 \mathrm{Y}$ variants [48]. Here, an early AMD-like phenotype was observed with drusen-like deposits forming; however, this occurred with both the $402 \mathrm{H}$ and $402 \mathrm{Y}$ forms. The lack 
of a difference between the $402 \mathrm{H}$ and $402 \mathrm{Y}$ phenotypes may be because the HS ZIP code is not conserved between species [49], such that the human CCP6-8 region cannot recruit the chimeric $\mathrm{CFH}$ to Bruch's membrane. Furthermore, it should be noted that mouse models of inflammatory disease often poorly mimic the gene expression changes observed in man [50]. Sadly, no fully satisfactory animal model yet exists for AMD, making its use for the evaluation of potential therapeutic interventions problematic.

\section{Summary}

The structural diversity of HS allows it to be utilized as a versatile ZIP code to specify precise tissue locations. Here, we have described how $\mathrm{CFH}$ recognizes particular HS structures, allowing it to bind to host tissues and prevent the spontaneous activation of the alternative complement pathway (e.g. in the human eye). Two different regions of $\mathrm{CFH}$ have distinct HS-binding properties providing tissue-specific recognition for Bruch's membrane
(CCP6-8) or the glomerular basement membrane (CCP19-20). Importantly, this tissue specificity at the protein level may help explain the genetic basis of AMD and aHUS and provides new insights into the pathogenic mechanisms for these diseases of complement dysregulation. However, further research is needed to more fully understand how the interaction between CFH and HS ZIP codes contributes to the initiation and progression of AMD.

\section{Acknowledgements}

We would like to thank Fight for Sight (grant 1866), the Macular Disease Society, and the Medical Research Council (grants G0900592 and K004441) for their past and present funding. We would also like to acknowledge the important contributions of our many colleagues and collaborators to the research described in this review.

\section{Disclosure Statement}

The authors have no financial conflicts of interest.

\section{References}

1 Congdon N, O’Colmain B, Klaver CC, Klein R, Munoz B, Friedman DS, Kempen J, Taylor HR, Mitchell P, Eye Diseases Prevalence Research Group: Causes and prevalence of visual impairment among adults in the United States. Arch Ophthalmol 2004;122:477-485.

- 2 Fritsche LG, Chen W, Schu M, Yaspan BL, Yu Y, Thorleifsson G, Zack DJ, Arakawa S, Cipriani V, Ripke S, Igo RP Jr, Buitendijk GH, Sim $\mathrm{X}$, Weeks DE, Guymer RH, Merriam JE, Francis PJ, Hannum G, Agarwal A, Armbrecht AM, Audo I, Aung T, Barile GR, Benchaboune M, Bird AC, Bishop PN, Branham KE, Brooks M, Brucker AJ, Cade WH, Cain MS, Campochiaro PA, Chan CC, Cheng CY, Chew EY, Chin KA, Chowers I, Clayton DG, Cojocaru R, Conley YP, Cornes BK, Daly MJ, Dhillon B, Edwards AO, Evangelou E, Fagerness J, Ferreyra HA, Friedman JS, Geirsdottir A, George RJ, Gieger C, Gupta N, Hagstrom SA, Harding SP, Haritoglou C, Heckenlively JR, Holz FG, Hughes G, Ioannidis JP, Ishibashi T, Joseph P, Jun G, Kamatani Y, Katsanis N, C NK, Khan JC, Kim IK, Kiyohara Y, Klein BE, Klein R, Kovach JL, Kozak I, Lee CJ, Lee KE, Lichtner P, Lotery AJ, Meitinger T, Mitchell P, Mohand-Said S, Moore AT, Morgan DJ, Morrison MA, Myers CE, Naj AC, Nakamura Y, Okada Y, Orlin A, Ortube MC, Othman MI, Pappas C, Park KH, Pauer GJ, Peachey NS, Poch O, Priya RR, Reynolds R, Richardson AJ, Ripp R, Rudolph G, Ryu E, Sahel JA, Schaumberg DA, Scholl HP, Schwartz
SG, Scott WK, Shahid H, Sigurdsson H, Silvestri G, Sivakumaran TA, Smith RT, Sobrin L, Souied EH, Stambolian DE, Stefansson H, Sturgill-Short GM, Takahashi A, Tosakulwong N, Truitt BJ, Tsironi EE, Uitterlinden AG, van Duijn CM, Vijaya L, Vingerling JR, Vithana EN, Webster AR, Wichmann HE, Winkler TW, Wong TY, Wright AF, Zelenika D, Zhang M, Zhao L, Zhang K, Klein ML, Hageman GS, Lathrop GM, Stefansson K, Allikmets R, Baird PN, Gorin MB, Wang JJ, Klaver CC, Seddon JM, Pericak-Vance MA, Iyengar SK, Yates JR, Swaroop A, Weber BH, Kubo M, Deangelis MM, Leveillard T, Thorsteinsdottir U, Haines JL, Farrer LA, Heid IM, Abecasis GR, AMD Gene Consortium: Seven new loci associated with age-related macular degeneration. Nat Genet 2013;45:433-439, 439e1-439e2.

-3 Cipriani V, Leung HT, Plagnol V, Bunce C, Khan JC, Shahid H, Moore AT, Harding SP, Bishop PN, Hayward C, Campbell S, Armbrecht AM, Dhillon B, Deary IJ, Campbell H, Dunlop M, Dominiczak AF, Mann SS, Jenkins SA, Webster AR, Bird AC, Lathrop M, Zelenika D, Souied EH, Sahel JA, Leveillard T, French AMDI, Cree AJ, Gibson J, Ennis S, Lotery AJ, Wright AF, Clayton DG, Yates JR: Genome-wide association study of age-related macular degeneration identifies associated variants in the TNXB-FKBPL-NOTCH4 region of chromosome 6p21.3. Hum Mol Genet 2012;21:4138-4150.
4 Sofat R, Casas JP, Webster AR, Bird AC, Mann SS, Yates JR, Moore AT, Sepp T, Cipriani V, Bunce C, Khan JC, Shahid H, Swaroop A, Abecasis G, Branham KE, Zareparsi S, Bergen AA, Klaver CC, Baas DC, Zhang K, Chen Y, Gibbs D, Weber BH, Keilhauer CN, Fritsche LG, Lotery A, Cree AJ, Griffiths HL, Bhattacharya SS, Chen LL, Jenkins SA, Peto T, Lathrop M, Leveillard T, Gorin MB, Weeks DE, Ortube MC, Ferrell RE, Jakobsdottir J, Conley YP, Rahu M, Seland JH, Soubrane G, Topouzis F, Vioque J, Tomazzoli L, Young I, Whittaker J, Chakravarthy U, de Jong PT, Smeeth L, Fletcher A, Hingorani AD: Complement factor $\mathrm{H}$ genetic variant and age-related macular degeneration: effect size, modifiers and relationship to disease subtype. Int J Epidemiol 2012;41:250-262.

-5 Fritsche LG, Lauer N, Hartmann A, Stippa S, Keilhauer CN, Oppermann M, Pandey MK, Kohl J, Zipfel PF, Weber BH, Skerka C: An imbalance of human complement regulatory proteins CFHR1, CFHR3 and factor $\mathrm{H}$ influences risk for age-related macular degeneration (AMD). Hum Mol Genet 2010;19:46944704.

6 Hughes AE, Orr N, Esfandiary H, Diaz-Torres M, Goodship T, Chakravarthy U: A common CFH haplotype, with deletion of CFHR1 and CFHR3, is associated with lower risk of age-related macular degeneration. Nat Genet 2006;38:1173-1177. 
7 Anderson DH, Radeke MJ, Gallo NB, Chapin EA, Johnson PT, Curletti CR, Hancox LS, Hu J, Ebright JN, Malek G, Hauser MA, Rickman CB, Bok D, Hageman GS, Johnson LV: The pivotal role of the complement system in aging and age-related macular degeneration: hypothesis re-visited. Prog Retin Eye Res 2010;29:95-112.

8 Rudnicka AR, Jarrar Z, Wormald R, Cook DG, Fletcher A, Owen CG: Age and gender variations in age-related macular degeneration prevalence in populations of European ancestry: a meta-analysis. Ophthalmology 2012;119:571-580.

9 Ferris FL 3rd, Wilkinson CP, Bird A, Chakravarthy U, Chew E, Csaky K, Sadda SR: Beckman initiative for macular research classification C: clinical classification of age-related macular degeneration. Ophthalmology 2013; 120:844-851.

10 Hageman GS, Luthert PJ, Victor Chong NH, Johnson LV, Anderson DH, Mullins RF: An integrated hypothesis that considers drusen as biomarkers of immune-mediated processes at the RPE-Bruch's membrane interface in aging and age-related macular degeneration. Prog Retin Eye Res 2001;20:705-732.

11 Booij JC, Baas DC, Beisekeeva J, Gorgels TG, Bergen AA: The dynamic nature of Bruch's membrane. Prog Retin Eye Res 2010;29:1-18.

$\checkmark 12$ Day AJ, Willis AC, Ripoche J, Sim RB: Sequence polymorphism of human complement factor H. Immunogenetics 1988;27: 211-214.

13 Ripoche J, Day AJ, Harris TJ, Sim RB: The complete amino acid sequence of human complement factor H. Biochem J 1988;249: 593-602.

14 Avery RL: The plague and macular degeneration. Ophthalmology 2010;117:2442.

15 Seddon JM, Yu Y, Miller EC, Reynolds R, Tan PL, Gowrisankar S, Goldstein JI, Triebwasser M, Anderson HE, Zerbib J, Kavanagh D, Souied E, Katsanis N, Daly MJ, Atkinson JP, Raychaudhuri S: Rare variants in CFI, C3 and $\mathrm{C} 9$ are associated with high risk of advanced age-related macular degeneration. Nat Genet 2013;45:1366-1370.

16 Makou E, Herbert AP, Barlow PN: Functional anatomy of complement factor H. Biochemistry 2013;52:3949-3962.

17 Clark SJ, Higman VA, Mulloy B, Perkins SJ, Lea SM, Sim RB, Day AJ: His-384 allotypic variant of factor $\mathrm{H}$ associated with age-related macular degeneration has different heparin binding properties from the non-disease-associated form. J Biol Chem 2006;281:2471324720.

18 Clark SJ, Bishop PN, Day AJ: Complement factor $\mathrm{H}$ and age-related macular degeneration: the role of glycosaminoglycan recognition in disease pathology. Biochem Soc Trans 2010;38:1342-1348.

$>19$ Khandhadia S, Cipriani V, Yates JR, Lotery AJ: Age-related macular degeneration and the complement system. Immunobiology 2012; 217:127-146.
20 Day AJ, Clark SJ, Bishop PN: Understanding the molecular basis of age-related macular degeneration and how the identification of new mechanisms may aid the development of novel therapies. Exp Rev Ophthalmol 2011;6: 123-128.

21 Weismann D, Hartvigsen K, Lauer N, Bennett KL, Scholl HP, Charbel Issa P, Cano M, Brandstatter H, Tsimikas S, Skerka C, Superti-Furga G, Handa JT, Zipfel PF, Witztum JL, Binder CJ: Complement factor $\mathrm{H}$ binds malondialdehyde epitopes and protects from oxidative stress. Nature 2011;478: 76-81.

22 Sjöberg AP, Trouw LA, Clark SJ, Sjolander J, Heinegard D, Sim RB, Day AJ, Blom AM: The factor $\mathrm{H}$ variant associated with age-related macular degeneration (His-384) and the nondisease-associated form bind differentially to C-reactive protein, fibromodulin, DNA, and necrotic cells. J Biol Chem 2007;282:1089410900.

-23 Prosser BE, Johnson S, Roversi P, Herbert AP, Blaum BS, Tyrrell J, Jowitt TA, Clark SJ, Tarelli E, Uhrin D, Barlow PN, Sim RB, Day AJ, Lea SM: Structural basis for complement factor $\mathrm{H}$ linked age-related macular degeneration. J Exp Med 2007;204:2277-2283.

24 Clark SJ, Perveen R, Hakobyan S, Morgan BP, Sim RB, Bishop PN, Day AJ: Impaired binding of the age-related macular degeneration-associated complement factor $\mathrm{H}$ $402 \mathrm{H}$ allotype to Bruch's membrane in human retina. J Biol Chem 2010;285:3019230202.

25 Bishop JR, Schuksz M, Esko JD: Heparan sulphate proteoglycans fine-tune mammalian physiology. Nature 2007;446:1030-1037.

26 Turnbull JE: Heparan sulfate glycomics: towards systems biology strategies. Biochem Soc Trans 2010;38:1356-1360.

27 Langford-Smith A, Wilkinson FL, LangfordSmith KJ, Holley RJ, Sergijenko A, Howe SJ, Bennett WR, Jones SA, Wraith J, Merry CL, Wynn RF, Bigger BW: Hematopoietic stem cell and gene therapy corrects primary neuropathology and behavior in mucopolysaccharidosis IIIA mice. Mol Ther 2012;20: 1610-1621.

28 Meade KA, White KJ, Pickford CE, Holley RJ, Marson A, Tillotson D, van Kuppevelt TH, Whittle JD, Day AJ, Merry CL: Immobilization of heparan sulfate on electrospun meshes to support embryonic stem cell culture and differentiation. J Biol Chem 2013;288:55305538.

29 Clark SJ, Keenan TD, Fielder HL, Collinson LJ, Holley RJ, Merry CL, van Kuppevelt TH, Day AJ, Bishop PN: Mapping the differential distribution of glycosaminoglycans in the adult human retina, choroid, and sclera. Invest Ophthalmol Vis Sci 2011;52:65116521.

30 Keenan TD, Clark SJ, Unwin RD, Ridge LA, Day AJ, Bishop PN: Mapping the differential distribution of proteoglycan core proteins in the adult human retina, choroid, and sclera.
Invest Ophthalmol Vis Sci 2012;53:75287538.

31 Kim DD, Song WC: Membrane complement regulatory proteins. Clin Immunol 2006;118: 127-136.

32 Clark SJ, Ridge LA, Herbert AP, Hakobyan S, Mulloy B, Lennon R, Wurzner R, Morgan BP, Uhrin D, Bishop PN, Day AJ: Tissue-specific host recognition by complement factor $\mathrm{H}$ is mediated by differential activities of its glycosaminoglycan-binding regions. J Immunol 2013;190:2049-2057.

33 Zaferani A, Vives RR, van der Pol P, Navis GJ, Daha MR, van Kooten C, Lortat-Jacob H, Seelen MA, van den Born J: Factor H and properdin recognize different epitopes on renal tubular epithelial heparan sulfate. J Biol Chem 2012;287:31471-31481.

34 Raychaudhuri S, Iartchouk O, Chin K, Tan PL, Tai AK, Ripke S, Gowrisankar S, Vemuri S, Montgomery K, Yu Y, Reynolds R, Zack DJ, Campochiaro B, Campochiaro P, Katsanis N, Daly MJ, Seddon JM: A rare penetrant mutation in $\mathrm{CFH}$ confers high risk of age-related macular degeneration. Nat Genet 2011;43: 1232-1236.

-35 Manuelian T, Hellwage J, Meri S, Caprioli J, Noris M, Heinen S, Jozsi M, Neumann HP, Remuzzi G, Zipfel PF: Mutations in factor $\mathrm{H}$ reduce binding affinity to $\mathrm{C} 3 \mathrm{~b}$ and heparin and surface attachment to endothelial cells in hemolytic uremic syndrome. J Clin Invest 2003;111:1181-1190.

36 Sanchez-Corral P, Perez-Caballero D, Huarte O, Simckes AM, Goicoechea E, Lopez-Trascasa M, de Cordoba SR: Structural and functional characterization of factor $\mathrm{H}$ mutations associated with atypical hemolytic uremic syndrome. Am J Hum Genet 2002;71:12851295.

37 Charbel Issa P, Chong NV, Scholl HP: The significance of the complement system for the pathogenesis of age-related macular degeneration - current evidence and translation into clinical application. Graefes Arch Clin Exp Ophthalmol 2011;249:163-174.

- 38 Smailhodzic D, Klaver CC, Klevering BJ, Boon CJ, Groenewoud JM, Kirchhof B, Daha MR, den Hollander AI, Hoyng CB: Risk alleles in CFH and ARMS2 are independently associated with systemic complement activation in age-related macular degeneration. Ophthalmology 2012;119:339-346.

39 Hecker LA, Edwards AO, Ryu E, Tosakulwong N, Baratz KH, Brown WL, Charbel Issa P, Scholl HP, Pollok-Kopp B, Schmid-Kubista KE, Bailey KR, Oppermann M: Genetic control of the alternative pathway of complement in humans and age-related macular degeneration. Hum Mol Genet 2010;19:209-215.

40 Johnson PT, Betts KE, Radeke MJ, Hageman GS, Anderson DH, Johnson LV: Individuals homozygous for the age-related macular degeneration risk-conferring variant of complement factor $\mathrm{H}$ have elevated levels of CRP in the choroid. Proc Natl Acad Sci USA 2006; 103:17456-17461. 
41 Mullins RF, Dewald AD, Streb LM, Wang K, Kuehn MH, Stone EM: Elevated membrane attack complex in human choroid with high risk complement factor $\mathrm{H}$ genotypes. Exp Eye Res 2011;93:565-567.

42 Krohne TU, Stratmann NK, Kopitz J, Holz FG: Effects of lipid peroxidation products on lipofuscinogenesis and autophagy in human retinal pigment epithelial cells. Exp Eye Res 2010;90:465-471.

43 Mihlan M, Blom AM, Kupreishvili K, Lauer N, Stelzner K, Bergstrom F, Niessen HW, Zipfel PF: Monomeric C-reactive protein modulates classic complement activation on necrotic cells. FASEB J 2011;25:4198-4210.

-44 Lauer N, Mihlan M, Hartmann A, SchlotzerSchrehardt U, Keilhauer C, Scholl HP, Charbel Issa P, Holz F, Weber BH, Skerka C, Zipfel PF: Complement regulation at necrotic cell lesions is impaired by the age-related macular degeneration-associated factor-H His402 risk variant. J Immunol 2011;187:4374-4383.

45 Feyzi E, Saldeen T, Larsson E, Lindahl U, Salmivirta M: Age-dependent modulation of heparan sulfate structure and function. J Biol Chem 1998;273:13395-13398.

46 Pennesi ME, Neuringer M, Courtney RJ: Animal models of age related macular degeneration. Mol Aspects Med 2012;33:487-509.
47 Coffey PJ, Gias C, McDermott CJ, Lundh P, Pickering MC, Sethi C, Bird A, Fitzke FW, Maass A, Chen LL, Holder GE, Luthert PJ, Salt TE, Moss SE, Greenwood J: Complement factor $\mathrm{H}$ deficiency in aged mice causes retinal abnormalities and visual dysfunction. Proc Natl Acad Sci USA 2007;104:16651-16656.

48 Ufret-Vincenty RL, Aredo B, Liu X, McMahon A, Chen PW, Sun H, Niederkorn JY, Kedzierski W: Transgenic mice expressing variants of complement factor $\mathrm{H}$ develop AMD-like retinal findings. Invest Ophthalmol Vis Sci 2010;51:5878-5887.

49 Toida T, Yoshida H, Toyoda H, Koshiishi I, Imanari T, Hileman RE, Fromm JR, Linhardt RJ: Structural differences and the presence of unsubstituted amino groups in heparan sulphates from different tissues and species. Biochem J 1997;322:499-506.

50 Seok J, Warren HS, Cuenca AG, Mindrinos MN, Baker HV, Xu W, Richards DR, McDonald-Smith GP, Gao H, Hennessy L, Finnerty CC, Lopez CM, Honari S, Moore EE, Minei JP, Cuschieri J, Bankey PE, Johnson JL, Sperry J, Nathens AB, Billiar TR, West MA, Jeschke MG, Klein MB, Gamelli RL, Gibran NS, Brownstein BH, Miller-Graziano C, Calvano SE, Mason PH, Cobb JP, Rahme LG, Lowry SF, Maier RV, Moldawer LL, Herndon DN, Davis RW, Xiao W, Tompkins RG, Inflammation and Host Response to Injury, Large Scale Collaborative Research Program: Genomic responses in mouse models poorly mimic human inflammatory diseases. Proc Natl Acad Sci USA 2013;110:3507-3512.
1 Thakkinstian A, McEvoy M, Chakravarthy U, Chakrabarti S, McKay GJ, Ryu E, Silvestri G, Kaur I, Francis P, Iwata T, Akahori M, Arning A, Edwards AO, Seddon JM, Attia J: The association between complement component $2 /$ complement factor B polymorphisms and age-related macular degeneration: a huge review and meta-analysis. Am J Epidemiol 2012;176:361-372.

52 Thakkinstian A, McKay GJ, McEvoy M, Chakravarthy U, Chakrabarti S, Silvestri G, Kaur I, Li X, Attia J: Systematic review and meta-analysis of the association between complement component 3 and age-related macular degeneration: a huge review and meta-analysis. Am J Epidemiol 2011;173:13651379.

53 Galor A, Lee DJ: Effects of smoking on ocular health. Curr Opin Ophthalmol 2011;22:477482 .

54 Parekh N, Voland RP, Moeller SM, Blodi BA, Ritenbaugh C, Chappell RJ, Wallace RB, Mares JA, Group CRS: Association between dietary fat intake and age-related macular degeneration in the Carotenoids in Age-related Eye Disease Study (CAREDS): an ancillary study of the Women's Health Initiative. Arch Ophthalmol 2009;127:1483-1493. 